\title{
PKM UPAYA PENGENDALIAN GULMA TANAMAN PADI BERBASIS TEKNOLOGI PADA KELOMPOK TANI DESA SEMIRING
}

\author{
Yasmini Suryaningsih ${ }^{1)}$, Eko Surjadi ${ }^{2)}$ \\ 1) jasminumsambac95@gmail.com \\ ${ }^{1)}$ Universitas Abdurachman Saleh Situbondo \\ ${ }^{2)}$ Universitas Surakarta
}

\begin{abstract}
Abstrak: Pengendalian gulma dengan cara mekanik yaitu dengan menggunakan landak/gasrok ini dilakukan dua kali dalam kurun waktu tiga bulan, ketika usia tanaman padi dua minggu dan enam minggu (setelah pemupukan), hal ini menguntungkan bagi buruh tani apalagi jika dilakukan diareal yang luas dan memakan waktu berhari-hari. Tetapi tidak demikian dengan petani dan konsumen beras, karena petani membutuhkan biaya yang besar untuk tenaga kerja yang tidak sedikit dan dilakukan berhari hari, dan beban biaya tersebut akan ditanggung konsumen secara tidak langsung dengan naiknya harga beras. Untuk itu, perlu dicarikan alternatif solusi cara pengendalian gulma. Salah satu solusi yang dapat diberikan pada petani padi adalah mesin pengendali gulma. Mesin ini adalah hasil modifikasi yang dilakukan terhadap alat landak/gasrok yang masih mengandalkan tenaga manusia. Kegiatan Pengenalan dan aplikasi landak bermotor di kelompok tani desa Semiring meliputi peyuluhan tentang gulma pada tanaman padi, penyuluhan pengenalan landak bermotor dan aplikasi landak bermotor di sawah, kemudian dilanjutkan dengan pendampingan.
\end{abstract}

Kata Kunci: Gulma, Padi, landak bermotor

\section{PENDAHULUAN}

Kenaikan produktivitas padi yang rendah menunjukkan bahwa budidaya tanaman padi masih banyak mengalami beberapa kendala diantaranya turunnya kesuburan tanah dan organisme pengganggu tanaman (OPT). Salah satu organisme pengganggu tanaman yaitu keberadaan gulma pada lahan budidaya.

Gulma merupakan salah satu masalah utama dalam budidaya padi. Penurunan produksi padi secara nasional akibat gangguan gulma mencapai 15$42 \%$ untuk padi sawah dan $47-87 \%$ untuk padi gogo (Pitoyo, 2006). Gulma merupakan salah satu faktor pembatas pada produksi padi. Gulma yang tumbuh disekitar tanaman utama akan menurunkan kualitas dan hasil panen karena berkompetisi terhadap unsur hara, sinar matahari, air dan ruang tumbuh, selain itu gulma juga mempunyai sifat yang lebih rakus, dibandingkan dengan tanaman padi, dalam memperebutkan sarana tumbuh yaitu air, unsur hara, cahaya, CO2, dan ruang tumbuh (Sukman dan Yakup, 2002). Sembodo (2010) juga menyatakan 
bahwa keberadaan gulma dapat menurunkan jumlah hasil (kuantitas), mutu hasil (kualitas), meracuni tanaman, menurunkan nilai tanah, merusak dan menghambat penggunaan alat mekanik, menjadi inang hama dan penyakit tumbuhan, menambahnya biaya produksi. Selain penurunan produksi, gulma dapat menyebabkan biaya produksi yang lebih besar (Tungate et al., 2007). Smith (1983) mengemukakan bahwa efek gangguan gulma yang parah dan biasa terjadi adalah kehilangan hasil yang disebabkan oleh adanya kompetisi gulma dengan tanaman padi. Kehilangan hasil padi karena gulma di Filipina diperkirakan mencapai $11 \%$ pada musim kering dan $13 \%$ pada musim hujan.

Pengendalian gulma dapat dilakukan dengan dua cara yaitu dengan cara langsung dan tidak langsung. Pengendalian secara langsung meliputi penyiangan, mekanis dan herbisida, sedangkan pengendalian tidak langsung meliputi pengolahan tanah dan teknik budidaya (Noor dan Pane, 2002). Pengendalian gulma padi sawah yang umumnya sudah dilakukan oleh petani adalah dengan cara langsung yaitu penyiangan dengan tangan cara mekanis menggunaan alat landak/gasrok dengan tenaga manusia dan dengan cara kimiawi yaitu penggunaan herbisida. Pengendalian gulma dengan penyiangan, saat ini jarang dilakukan karena adanya keterbatasan tenaga penyiang padahal membutuhkan tenaga kkerja ang banyak, sedangkan dengan cara kimiawi membutuhkan waktu lebih cepat dan tenaga lebih sedikit tetapi bisa menyebabkan kerusakan tanah jika terakumulasi pada tanah baik secara biologi maupun fisika serta juga bisa menyebabkan kerusakan sementara pada tanaman padi. Pengendalian gulma dengan cara mekanik memiliki keunggulan daripada dua cara yang lainnya yaitu lebih efesien daripada penyiangan dengan tangan walaupun masih membutuhan banyak tenaga kerja juga, dan lebih efektif daripada cara kimiawi walaupun terkadang mengakibatkan kerusakan perakaran padi.

Pengendalian gulma dengan menggunakan landak/gasrok ini dilakukan dua kali dalam kurun waktu tiga bulan, ketika usia tanaman padi dua minggu dan enam minggu (setelah pemupukan), hal ini menguntungkan bagi buruh tani apalagi jika dilakukan diareal yang luas dan memakan waktu berhari-hari. Tetapi tidak demikian dengan petani dan konsumen beras, karena petani membutuhkan biaya yang besar untuk tenaga kerja yang tidak sedikit dan dilakukan berhari hari, 
dan beban biaya tersebut akan ditanggung konsumen secara tidak langsung dengan naiknya harga beras. Permasalahan inilah yang sering dihadapi petani khususnya yg menggunakan cara mekanik dalam menanggulangi gulma seperti kelompok tani di Desa Semiring Kabupaten Situbondo.

landak/gasrok adalah pengendali gulma yang digerakkan oleh tenaga manusia sehingga kurang efisien, oleh sebab itu perlu direkayasa agar lebih hemat waktu dan memenuhi harapan petani. Mesin pengendali gulma adalah salah satu solusi yang dapat diberikan kepada petani, khususnya petani padi.

Modifikasi landak/gasrok adalah dengan memberikan tambahan motor bensin stasioner dan pemindah daya dari mesin potong rumput panggul maka landak/gasrok yang semula bertenaga manusia menjadi bertenaga motor bakar.

\section{METODE PELAKSANAAN}

Kerangka berpikir untuk memecahkan masalah kegiatan ini digambarkan seperti pada Gambar 1. Dari permasalahan yang muncul disusun berbagai alternatif untuk memecahkan masalah. Selanjutnya dari berbagai alternatif, dipilih alternatif yang paling mungkin dilaksanakan. Berdasarkan kerangka berpikir tersebut, maka metode dalam kegiatan ini adalah sebagai berikut 


\section{Permasalahan}

- Mitra kurang memahami tentang gulma dan akibatnya

- Mitra kurang mengetahui perbedaan alat pengendali gulma secara manual dengan yang bermotor.

- Mitra kurang mengetahui cara penggunaan alat pengendali gulma bermotor

\section{Metode Kegiatan}

- Ceramah

- Diskusi

- Praktik langsung

\section{Pemecahan Masalah}

- Meningkatkan pengetahuan tentang gulma dan akibatnya secara teori

- Meningkatakan pengetahuan perbedaan alat pengendali gulma secara manual dengan yang bermotor.

- Meningkatkan keterampilan cara penggunaan alat pengendali gulma bermotor

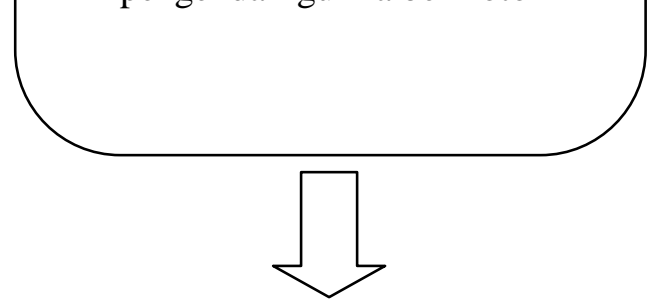

\section{Alternatif Pemecahan}

Masalah

- Meningkatkan pemahaman mitra tentang pengendalian gulma menggunaan alat pengendali gulma bermotor

Gambar 1. Bagan Skematis Metode Kegiatan

\section{HASIL DAN PEMBAHASAN}

\section{Penyuluhan Tentang Gulma Bagi Tanaman}

Kegiatan penyuluhan diikuti oleh Anggota kelompok tani Desa Semiring. Kegiatan ini dilaksanakan pada tanggal 11 Agustus 2018. Penyuluhan tentang Gulma dan akibatnya bagi tanaman pokok bertujuan untuk meningkatkan pengetahuan mitra secara teori tentang gulma dan dampana bagi tanaman pokok. 


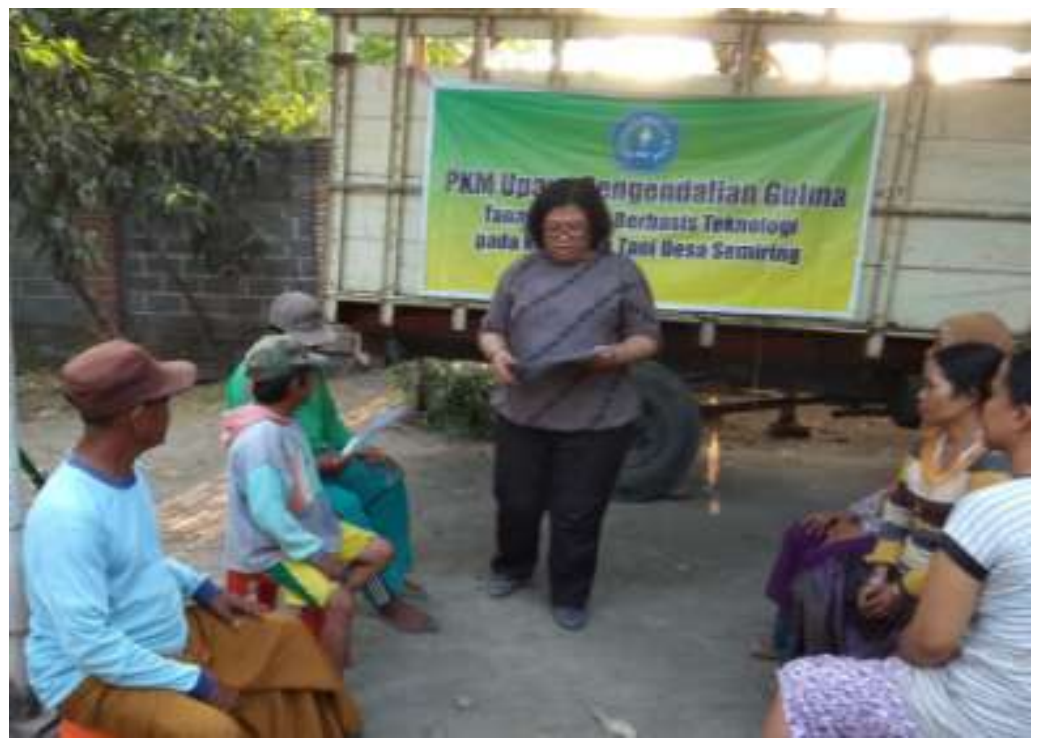

Gambar 2. Penyuluhan tentang gulma

\section{Penyuluhan Pengenalan landak bermotor}

Penyuluhan tentang perbedaan alat pengendali gulma atau landak manual dengan bermotor merupakan kelanjutan dari penyuluhan tentang beberapa teknologi tepat guna untuk petani. Pada kegiatan ini, mitra diperkenalkan landak bermotor yang merupakan pengembangan dari landak manual dan disarkan berdasarkan jenis tanah di lokasi penyuluhan. Tujuan dari penyuluhan ini yaitu memperkenalkan landak bermotor dan memperbandingkan kecepatan penggunaannya dengan landak manual. Penyuluhan dilaksanakan pada tanggal 11Agustus 2018 yang dihadiri oleh anggota mitra sebanyak 18 orang
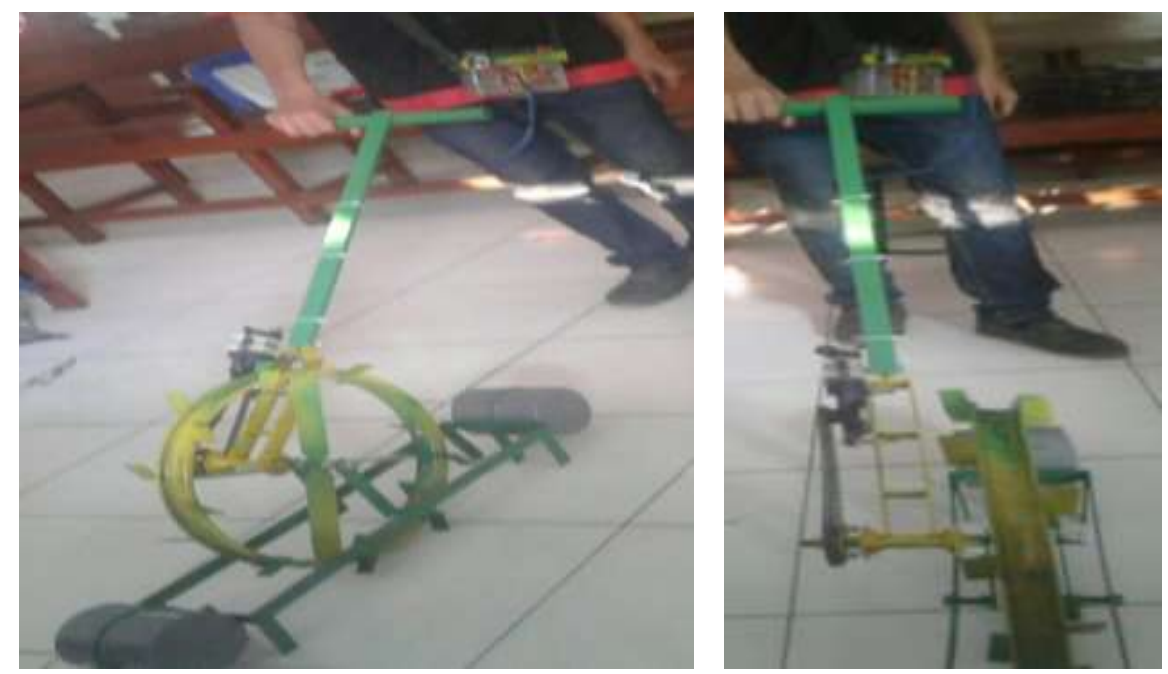

Gambar 3. Alat pengendali gulma / landak bermotor 


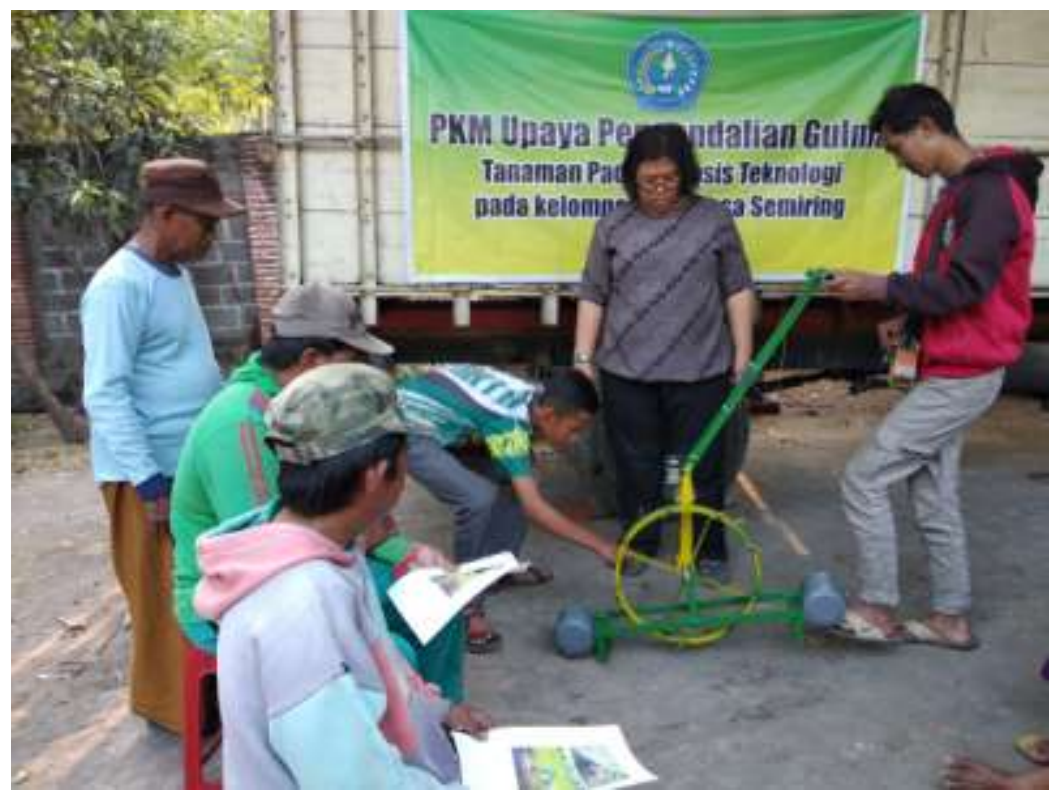

Gambar 4. Penyuluhan tentang perbedaan landak manual dengan bermotor dan cara kerjanya

\section{Demplot Aplikasi Landak Bermotor}

Demo plot (Demplot) di sawah milik salah satu anggota kelompok tani dilaksanakan pada tanggal 11 Agustus 2018. Tujuan dari demplot ini yaitu untuk meningkatkan pengetahuan petani tentang penggunaan landak bermotor dan merubah pemahaman petani tentang manfaat pengunaan teknologi tepat guna bagi petani.

Pelatihan pertama, dilakukan penyuluhan dengan metode ceramah dan praktik langsung. Mitra dapat melihat secara langsung penggunaan landak bermotor diaplikasikan di sawah dan cara pemeliharaan alat.

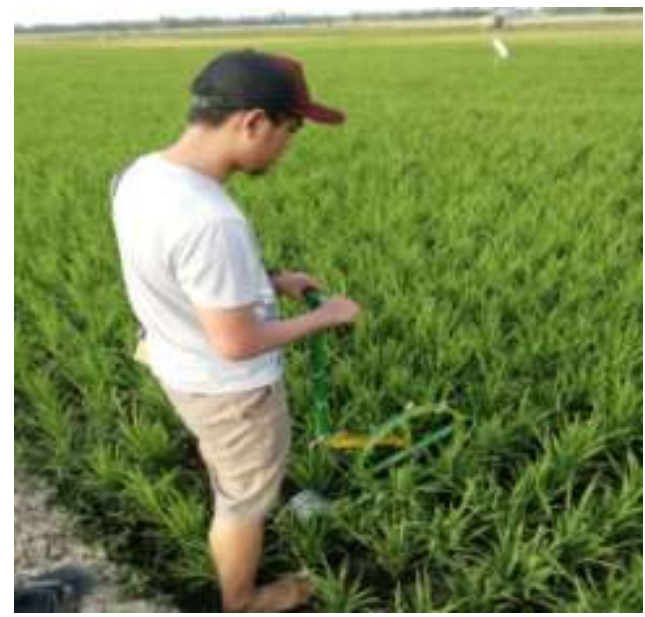

Gambar 5. Demplot penggunaan landak bermotor di sawah 
Kegiatan lanjutan dilakukan pendampingan langsung pada mitra. Pendampingan bertujuan untuk mentransfer pengetahuan dan keterampilan secara langsung pada mitra. Sehingga diharapkan materi pelatihan yang disampaikan

\section{KESIMPULAN}

Kesimpulan dari kegiatan ini adalah sebagai berikut :

1. Kegiatan yang telah dilakukan pada Pengendalian gulma padi dengan alat pengendali gulma bermotor diantaranya peyuluhan tentang gulma pada tanaman padi, penyuluhan pengenalan landak bermotor dan aplikasi landak bermotor di sawah, kemudian dilanjutkan dengan pendampingan.

2. Pelaksanaan pelatihan berjalan lancar dan antusias yang dihadiri oleh anggota kelompok tani desa semiring dengan peserta 18 orang.

\section{DAFTAR PUSTAKA}

Khurmi, R. S. \& Gupta, J. K. (1982). A Text Book of Machine Design. New Delhi: Eurasia Publishing House (Put.) LTD.

Noor E. S. dan H. Pane. 2002. Pengelolaan Gulma pada Sistem Usahatani Berbasis Padi di Lahan Sawah Tadah Hujan. Hlm. 321-335 Dalam J.Soejitno, I. J. Sasadan Hermanto (Ed). Prosiding Seminar Nasional Membangun Sistem ProduksiTanaman Pangan Berwawasan Lingkungan. Pusat Penelitian dan PengembanganTanaman Pangan Bogor. Bogor.Pitoyo J. 2006. Mesin Penyiang Gulma Padi Sawah. http//www.litbangdeptan. go.id. [20 Mei 2018].

Sato, G. T. (2000). Menggambar Mesin Menurut Standar ISO, Cetakan ke-9. Jakarta : PT. Pradnya Paramita

Smith R.J. 1983. Weeds of major economic importance in rice and yield losses due to weed competition. p 19-35. In: Weed Control in Rice. International Rice Research Institute. Los Banos. 264 p

Stepin, P. (1975). Strength Material. Moscow : Peace Publishers

Sugandi, W. K. (2011). Desain dan Kinerja Unit Pemotong Serasah Tebu dengan Menggunakan Pisau Tipe Reel, Tesis. Bogor : Sekolah Pasca Sarjana, IPB

Suga, K. \& Soelarso. (1991). Dasar Perencanaan dan Pemilihan Elemen Mesin, Edisi ke-7. PT. Jakarta : PT. Pradya Paramita. 
Sugiyanto, B. dan Mubtadi, B. I. (2013). Estimasi Kebutuhan Daya Alat Potong Gergaji Piringan untuk Mesin Pemanen Tebu. Medan : POLITEKNOSAINS VOL. XI NO. 2 Maret 2013, Politeknik Negeri Medan

Sugiyanto, B. dan Rizaldi, T.(2006). Torsi Gergaji Piringan untuk Memotong Batang Tanaman Tebu. Medan : Buletin Agricultural Engineering BEARING, Vol. 2, No. 1, Juni 2006, Program Studi Teknik Pertanian, Fakultas Pertanian USU

Sukman Y. dan Yakup. 2002. Gulma dan Teknik Pengendaliannya. PT Gafindo. Jakarta.

Titherington, D., Rimmer, J. G. \& Prasetyo, L. (1984). Mekanika Terapan, Edisi ke-2. Jakarta : Penerbit Erlangga.

Tungate K.D., Israel D.W., Watson D.M. and Ruffy T.W. 2007. Potential changes in weed competitiveness in an agroecological system with elevated temperatures. Environ. And Exp. Bot. 